\title{
A comparison of two insulin infusion protocols in the medical intensive care unit by continuous glucose monitoring
}

\author{
Christophe E. M. De Block ${ }^{1 *}$, Peter Rogiers ${ }^{2}$, Philippe G. Jorens ${ }^{3}$, Tom Schepens ${ }^{3}$, Cosimo Scuffi ${ }^{4}$ \\ and Luc F. Van Gaal ${ }^{1}$
}

\begin{abstract}
Background: Achieving good glycemic control in intensive care units (ICU) requires a safe and efficient insulin infusion protocol (IIP). We aimed to compare the clinical performance of two IIPs (Leuven versus modified Yale protocol) in patients admitted to medical ICU, by using continuous glucose monitoring (CGM). This is a pooled data analysis of two published prospective randomized controlled trials. CGM monitoring was performed in 57 MICU patients (age $64 \pm 12$ years, APACHE-II score $28 \pm 7$, non-diabetic/diabetic: 36/21). The main outcome measures were percentage of time in normoglycemia ( $80-110 \mathrm{mg} / \mathrm{dl}$ ) and in hypoglycemia $(<60 \mathrm{mg} / \mathrm{dl})$, and glycemic variability (standard deviation, coefficient of variation, mean amplitude of glucose excursions, mean of daily differences).

Results: Twenty-two subjects were treated using the Leuven protocol and 35 by the Yale protocol; >63,000 CGM measurements were available. The percentage of time in normoglycemia $(80-110 \mathrm{mg} / \mathrm{dl})$ was higher (37 $\pm 15 \mathrm{vs}$. $26 \pm 11 \%, p=0.001)$ and percentage of time spent in hypoglycemia was lower (0[0-2] vs. 5[1-8]\%, $p=0.001)$ in the Yale group. Median glycemia did not differ between groups (118[108-128] vs. 128[106-154] mg/dl). Glycemic variability was less pronounced in the Yale group (median SD 28[21-37] vs. 47[31-71] $\mathrm{mg} / \mathrm{dl}, p=0.001$; CV 23[19-31] vs. 36[26-50]\%, $p=0.001 ;$ MODD 35[26-41] vs. 60[33-94] mg/dl, $p=0.001$ ). However, logistic regression could not identify type of IIP, diabetes status, age, BMI, or APACHE-II score as independent parameters for strict glucose control.

Conclusions: The Yale protocol provided better average glycemia, more time spent in normoglycemia, less time in hypoglycemia, and less glycemic variability than the Leuven protocol, but was not independently associated with strict glycemic control.
\end{abstract}

Keywords: Intensive care unit, Continuous glucose monitoring, Insulin infusion protocol, Hypoglycemia

\section{Background}

Consensus exists that overt hyperglycemia (>150 mg/ $\mathrm{dl}$ ) in patients admitted to the intensive care unit (ICU) should be treated to improve morbidity and survival [1]. However, there is little agreement on the ideal target range of glycemia [2]. Strict glycemic control (80$110 \mathrm{mg} / \mathrm{dl}$ ) is no longer recommended for most ICUs,

\footnotetext{
*Correspondence: christophe.deblock@uantwerpen.be; christophe.deblock@uza.be

${ }^{1}$ Department of Endocrinology, Diabetology and Metabolism, Faculty of Medicine, Antwerp University Hospital and University of Antwerp, Wilrijkstraat 10,2650 Edegem, Belgium

Full list of author information is available at the end of the article
}

but in highly standardized ICUs a strict target may be feasible without increasing hypoglycemia. Achieving strict glycemic control is a complex task since during ICU stay severity of illness and degree of insulin resistance may fluctuate, nutritional delivery may change, and interventions (e.g., administration of corticosteroids) may produce frequent changes in insulin needs [2]. Therefore, multiple insulin infusion protocols (IIPs) were created, all meant to balance efficacy with safety (avoid hypoglycemia), and attainability (nursing workload).

So far, no single IIP has been established as the most effective for obtaining tight glycemic control. Earlier observational studies and randomized controlled trials 
(RCTs) in medical ICU (MICU) or mixed ICU settings, and targeting a glycemia between 80 and $110 \mathrm{mg} / \mathrm{dl}$, reported that $22-60 \%$ of all blood glucose values were in target for paper-based IIPs [3-14], compared to 42-69\% for computerized decision-supported algorithms [4, 10, $11,14,15]$. The efficacy and safety of different IIPs on glycemic control have recently been investigated using computer simulation models $[16,17]$ and in RCTs in cardiac surgery patients $[18,19]$. However, to the best of our knowledge, comparing the effect of different IIPs on glucose control has never been investigated in MICU patients. With this pooled data analysis of two published prospective RCTs $[5,6]$, we assessed the clinical performance of two IIPs (Leuven versus modified Yale protocol) in patients admitted to MICU, by means of continuous glucose monitoring (CGM), allowing a complete picture of glucometrics.

\section{Methods}

This is a pooled data analysis of two prospective RCTs conducted at the medical ICUs of the Antwerp University Hospital (45 beds, including 14 MICU beds) and Middelheim Hospital, a university-affiliated tertiary care center (36 beds, including 13 MICU beds) [5, 6]. Patients were recruited between 04/2004 and 03/2005 for the first study and between 07/2007 and 09/2009 for the second study. Both MICUs applied the same standards of care, with a nurse-to-patient ratio between 1:2.5 and 1:3.0. Each patient or the closest family member gave written informed consent. Patients were included if they were between 18 and 75 years, treated by IV insulin, and expected to stay in MICU for $\geq 3$ days. Patients were not enrolled if pregnant, if surgery was the reason for admission, or if a do not reanimate code was present. The studies were approved by the ethics committees of both hospitals (Middelheim approval no. 2345 and UZA 6/43/211) and conducted in accordance with the amended Declaration of Helsinki.

Severity of illness was scored using the Acute Physiology And Chronic Health Evaluation II (APACHE-II) and the Sequential Organ Failure Assessment (SOFA) score $[20,21]$. The neurologic score was zero when patients were sedated. Enteral nutrition was started as soon as possible, at $25 \mathrm{kcal} / \mathrm{kg}$ body weight per day.

\section{Glucose monitoring}

Forty-eight-hour CGM was initiated within the first $48 \mathrm{~h}$ after admission using a microdialysis-based device that is not equipped with alarms (GlucoDay ${ }^{\circledR}$ in the first study and GlucoDay ${ }^{\circledR} \mathrm{S}$ in the second study, A. Menarini Diagnostics, Florence, Italy). The methodology has been described before [5, 6]. Briefly, a microdialysis fiber (Medica, Medolla, Italy) was inserted subcutaneously into the periumbilical region using an 18-gauge Tef$\operatorname{lon}^{\circledR}$ (DuPont, Wilmington, DE) catheter as a guide. The device does not use any coagulant. The device uses a glucose oxidase-based amperometric biosensor to measure glucose concentrations in the interstitial dialysate every 3 min over a $48 \mathrm{~h}$ period.

Data analysis for accuracy and glucometrics was performed by applying, in silico to the CGM signal, a two-point calibration according to the manufacturer's requirements (one calibration every $24 \mathrm{~h}$ ). This was performed in order to avoid an overestimation of the system's accuracy if one uses a higher number of calibration points. In the RT-CGM group, however, to be as safe as possible and to account for possible changes in subcutaneous glucose recovery due to hemodynamic alterations (e.g., hypotension, shock, vasoactive drugs), for each sensor, a six-point calibration was performed (after $2,6,12,18,24$, and $36 \mathrm{~h}$ ) using arterial BG values, but these data were not used for statistical analysis [6]. This was done to assure that the glucose readings and trends shown by RT-CGM would be clinically reliable. At present, RT-CGM is becoming more common practice, but at the time of the study, a real-time CGM device was not approved to make clinical adjustments of insulin therapy, and our ethical committee would not approve clinical decisions to be made solely on the basis of RT-CGM at that time. In order to avoid clinical decisions being made on potentially inaccurate CGM data, nurses had to take an additional arterial blood glucose sample. Thus, direct corroboration of the data was explicitly needed. The RTCGM system was thus used only as a prompt to take an extra blood glucose sample if the rate of change in glucose exceeded $25 \mathrm{mg} / \mathrm{dl}$ per $30 \mathrm{~min}$. Since no differences in glucometrics were observed in the REGIMEN trial between in patients randomized to RT-CGM versus blinded CGM, we pooled the data. For all patients, adjustments of insulin therapy were made on the basis of arterial blood glucose values [6].

\section{Insulin infusion protocols}

Twenty-two patients received continuous IV insulin (regular insulin Actrapid; Novo Nordisk, Bagsvaerd, Denmark) according to the Leuven protocol, targeting a blood glucose between 80 and $110 \mathrm{mg} / \mathrm{dl}[5,13]$. Thirty-five subjects were treated with IV insulin (insulin aspart, Novo Nordisk, Bagsvaerd, Denmark) according to a modified Yale protocol, targeting a blood glucose level between 80 and $120 \mathrm{mg} / \mathrm{dl}[6]$.

In both groups, arterial blood glucose levels were measured using an on-site blood gas analyzer (Rapidlab ${ }^{\circledR}$ 1265, Siemens, München, Germany) and they were used to adjust the insulin infusion rate. Insulin in a concentration of 50 units in $50 \mathrm{cc} 0.9 \% \mathrm{NaCl}$ was infused using 
the Injectomat Agilia ${ }^{\circledR}$ syringe infusion system (flow rate change: range 0.1-200 ml/h, Fresenius Kabi, Bad Homburg, Germany). In both groups, the arterial blood glucose sampling interval varied between 1 and $4 \mathrm{~h}$. For more details on the insulin infusion protocols, the reader is referred to the original publications $[5,6]$.

\section{Outcome parameters}

The percentage of time spent in the target range of glycemia $(80-110 \mathrm{mg} / \mathrm{dl})$ was the primary outcome parameter. Secondary outcome variables were percentages of time spent in hypoglycemia $(<60 \mathrm{mg} / \mathrm{dl})$, in hyperglycemia ( $>150$ and $>200 \mathrm{mg} / \mathrm{dl}$ ), and parameters of glycemic fluctuations (SD: standard deviation [22], CV: coefficient of variation [22], MAGE: mean amplitude of glucose excursions [23], CONGA: continuous overlapping net glycemic action [24], and MODD: mean of daily differences [25]. We also calculated the low blood glucose index (LBGI) and the high blood glucose index (HBGI) as measures of risk of hypo- and hyperglycemia [26]. All glucometric data reported are those calculated using CGM data. A CGM reading $<60 \mathrm{mg} / \mathrm{dl}$, confirmed by an arterial blood glucose sample $<60 \mathrm{mg} / \mathrm{dl}$, lasting for $>6 \mathrm{~min}(6 \mathrm{~min}$ being the time of two CGM measurements) was defined as a hypoglycemic event. We rigorously followed the recommendations on measurement of blood glucose and reporting glycemic control in critically ill adults [27].

\section{Statistical analysis}

Results were analyzed using SPSS (SPSS Inc., Chicago, USA). Distributions of continuous data were tested for normality by Kolmogorov-Smirnov test. The unpaired $t$ test or Mann-Whitney $U$ test were used to determine differences between groups, with Bonferroni adjustments for multiple comparisons. Data are expressed as mean \pm SD or median [25th-75th percentile]. Differences in distributions of categorical data were evaluated by $\chi^{2}$ or Fisher's exact test. Stepwise forward logistic or linear regression analysis was performed to assess the strength and independency of associations. A two-tailed $p<0.05$ was considered significant.

\section{Results}

Over 63,000 CGM data points were analyzed from 57 adults (men/women: 30/27, non-diabetic/diabetic: 36/21) admitted to the MICU. Mean age was $64 \pm 12$ years. They were severely ill as demonstrated by a mean APACHE-II score of $28 \pm 7$ and SOFA score of $10 \pm 4$. Table 1 shows reasons for admission and interventions used.

\section{Comparison of Leuven versus Yale protocol}

Twenty-two subjects were treated using the Leuven protocol and 35 by the Yale protocol. The distribution of diabetic subjects differed between groups (13/22 Leuven vs. $8 / 35$ Yale; $p=0.0016$ ). Patients in the Yale group tended to be older. Reasons for admission were comparable between groups with exception of neurologic disease/ coma. Feeding habits were different in the two groups $(p=0.003)$ with enteral feeding being less frequently used in the Leuven group (3/22 vs. 20/35). The APACHEII score was similar, whereas the SOFA score tended to be higher in the Yale group.

Patients in the Leuven group required much more IV insulin compared to those treated by the Yale protocol (Table 1). Despite a similar number of arterial blood glucose measurements, patients in the Yale protocol had better glucometrics with a higher percentage of time in target glycemia $(80-110 \mathrm{mg} / \mathrm{dl})(37 \pm 15 \mathrm{vs}$. $26 \pm 11 \%, p=0.001)$ and a lower percentage of time spent in hypoglycemia $(0[0-2]$ vs. $5[1-8] \%, p=0.001)$. Also percentage of time spent between 60 and $150 \mathrm{mg} / \mathrm{dl}$ ( $81 \pm 7$ vs. $66 \pm 24 \%, p<0.0001), 80-125 \mathrm{mg} / \mathrm{dl}(57 \pm 18$ vs. $36 \pm 21 \%, p<0.0001)$, between 80 and $145 \mathrm{mg} /$ $\mathrm{dl}$ (74 \pm 17 vs. $48 \pm 23, p<0.0001)$, and between 70 and $180 \mathrm{mg} / \mathrm{dl}(91 \pm 10$ vs. $69 \pm 19 \%, p<0.0001)$ was higher in the Yale group. Figure 1 shows the time-inband for the different ranges of targets for both groups. Median glycemia, however, did not differ between groups (118[108-128] (log: 114[105-125]) vs. 128[106-154] (log: 122[99-136]) mg/dl) (Table 1). Glycemic variability was less pronounced with the use of the Yale protocol (median[IQR] SD 28[21-37] vs. 47[31-71] mg/ $\mathrm{dl}, p=0.001$; median CV $23[19-31]$ vs. $36[26-50] \%$, $p=0.001$; median MODD 35[26-41] vs. $60[33-94] \mathrm{mg} /$ $\mathrm{dl}, p=0.001)$. Significant better LBGI and HBGI were observed in the Yale group (Table 1). Eight insulin/glucose plots comparing non-diabetic and diabetic patients treated according to the Leuven protocol versus according to the modified Yale protocol are shown in Fig. 2, providing the reader with a good visual image.

\section{Characteristics of subjects achieving strict versus above-target glycemic control}

Subjects achieving strict glycemic control $(n=19)$, defined as having an average glycemia $\leq 110 \mathrm{mg} / \mathrm{dl}$, did not differ with regard to gender, diabetic status, age, BMI, reason for admission, severity of illness, and interventions used as compared to the ones not obtaining an average glycemia $\leq 110 \mathrm{mg} / \mathrm{dl}$, with the exception of the use of glucocorticoids ( $p=0.001$ ) (Table 2). The distribution according to insulin infusion protocol used (Leuven vs. Yale) also did not differ between groups. Insulin doses infused and a number of arterial blood glucose measurements were similar as well. Most glucometrics (\% of time within target) including glycemic variability (SD, MODD, LBGI and HBGI) were better in the group achieving 
Table 1 Baseline characteristics, interventions used and glucometrics of patients treated by the Leuven versus Yale protocol

\begin{tabular}{|c|c|c|c|c|}
\hline & Total cohort & Leuven & Yale & Statistics \\
\hline Number of patients & 57 & 22 & 35 & $p$ value \\
\hline \multicolumn{5}{|l|}{ Patient demographics } \\
\hline Men/women & $30 / 27$ & $13 / 9$ & $17 / 18$ & NS \\
\hline Diabetic status (no/type1/type2) & $36 / 6 / 15$ & $9 / 4 / 9$ & $27 / 2 / 6$ & 0.0016 \\
\hline Age (years) & $64 \pm 12$ & $60 \pm 13$ & $66 \pm 10$ & 0.055 \\
\hline $\mathrm{BMI}\left(\mathrm{kg} / \mathrm{m}^{2}\right)$ & $26.8 \pm 5.4$ & $27.5 \pm 7.1$ & $26.3 \pm 4.0$ & NS \\
\hline \multicolumn{5}{|l|}{ Admission reason } \\
\hline Septic shock & 22 & 13 & 9 & NS \\
\hline Neurologic disease/coma & 9 & 0 & 9 & 0.004 \\
\hline Cardiopulmonary resuscitation & 9 & 1 & 8 & NS \\
\hline Respiratory failure & 6 & 1 & 5 & NS \\
\hline Cardiogenic shock & 7 & 3 & 4 & NS \\
\hline Other & 4 & 4 & 0 & NS \\
\hline \multicolumn{5}{|l|}{ Severity of illness } \\
\hline APACHE-II score & $28 \pm 7$ & $27 \pm 7$ & $28 \pm 7$ & NS \\
\hline SOFA score & $10 \pm 4$ & $9 \pm 4$ & $11 \pm 3$ & 0.072 \\
\hline \multicolumn{5}{|l|}{ Clinical interventions } \\
\hline Mechanical ventilation & 44 & 16 & 28 & NS \\
\hline Vasopressor therapy & 35 & 14 & 21 & NS \\
\hline Inotropic therapy & 20 & 6 & 14 & NS \\
\hline Hemodialysis & 14 & 9 & 5 & NS \\
\hline No/total parenteral/enteral feeding & $17 / 17 / 23$ & $9 / 10 / 3$ & $8 / 7 / 20$ & 0.003 \\
\hline Glucocorticoids & 27 & 12 & 15 & NS \\
\hline Blood transfusion & 15 & 4 & 11 & NS \\
\hline Antibiotics & 46 & 19 & 27 & NS \\
\hline \multicolumn{5}{|l|}{ Outcome parameters } \\
\hline LOS in ICU (days) & $15 \pm 9$ & $11 \pm 6$ & $17 \pm 10$ & 0.019 \\
\hline In hospital mortality & 20 & 7 & 11 & NS \\
\hline \multicolumn{5}{|l|}{ Insulin dose } \\
\hline Day 1 (units) & & $138(48-190)$ & $50(27-80)$ & 0.001 \\
\hline Day 2 (units) & & $116(54-116)$ & $56(28-81)$ & 0.006 \\
\hline \multicolumn{5}{|l|}{ Glucose parameters } \\
\hline $\mathrm{HbA1c}(\%)$ & & $6.3(5.8-7.0)$ & $6.0(5.7-6.6)$ & NS \\
\hline $\mathrm{HbA} 1 \mathrm{c}(\mathrm{mmol} / \mathrm{mol})$ & & $45(40-53)$ & $42(39-49)$ & NS \\
\hline Median glycemia (mg/dl) & & $128(106-154)$ & $118(108-128)$ & NS \\
\hline \multicolumn{5}{|l|}{$\%$ of time at glycemia } \\
\hline$<60 \mathrm{mg} / \mathrm{dl}$ & & $5(1-8)$ & $0(0-2)$ & 0.001 \\
\hline $80-110 \mathrm{mg} / \mathrm{dl}$ & & $26 \pm 11$ & $37 \pm 15$ & 0.001 \\
\hline$>150 \mathrm{mg} / \mathrm{dl}$ & & $29 \pm 23$ & $17 \pm 13$ & $<0.0001$ \\
\hline$>200 \mathrm{mg} / \mathrm{dl}$ & & $13 \pm 19$ & $3 \pm 5$ & $<0.0001$ \\
\hline $60-150 \mathrm{mg} / \mathrm{dl}$ & & $66 \pm 24$ & $81 \pm 7$ & $<0.0001$ \\
\hline $70-180 \mathrm{mg} / \mathrm{dl}$ & & $69 \pm 19$ & $91 \pm 10$ & $<0.0001$ \\
\hline Nr of art blood glc measurements/day & & $10 \pm 2$ & $10 \pm 4$ & NS \\
\hline \multicolumn{5}{|l|}{ Glucose variability parameters } \\
\hline $\mathrm{SD}(\mathrm{mg} / \mathrm{dl})$ & & $47(31-71)$ & $28(21-37)$ & 0.001 \\
\hline Coefficient of variation (\%) & & $36(26-50)$ & $23(19-31)$ & 0.001 \\
\hline $\mathrm{IQR}$ & & $66(47-82)$ & $37(27-43)$ & $<0.0001$ \\
\hline MAGE (mg/dl) & & $73(47-128)$ & $52(37-83)$ & 0.061 (NS) \\
\hline
\end{tabular}


Table 1 continued

\begin{tabular}{|c|c|c|c|c|}
\hline & Total cohort & Leuven & Yale & Statistics \\
\hline MODD (mg/dl) & & 60 (33-94) & $35(26-41)$ & 0.001 \\
\hline$M-100$ & & $10(4-25)$ & $4(2-5)$ & $<0.0001$ \\
\hline CONGA1 (mg/dl) & & $20(14-39)$ & $15(13-24)$ & NS \\
\hline CONGA2 (mg/dl) & & $30(22-53)$ & $23(18-34)$ & 0.036 \\
\hline CONGA4 (mg/dl) & & $38(28-66)$ & $29(20-43)$ & 0.012 \\
\hline LBGI & & $2.6(1.0-3.7)$ & $0.7(0.4-1.4)$ & 0.011 \\
\hline $\mathrm{HBGl}$ & & $2.5(1.0-8.0)$ & $1.3(0.5-1.8)$ & 0.018 \\
\hline Glucose variability & & $42(29-67)$ & $28(20-34)$ & 0.001 \\
\hline
\end{tabular}

Data are presented as numbers, as mean \pm SD or median (25-75th percentile)

$\angle O S$ in ICU length of stay in ICU, IQR interquartile range, MAGE mean amplitude of glycemic excursions, MODD mean of daily differences, $L B G I$ low blood glucose index, HBGI high BGI

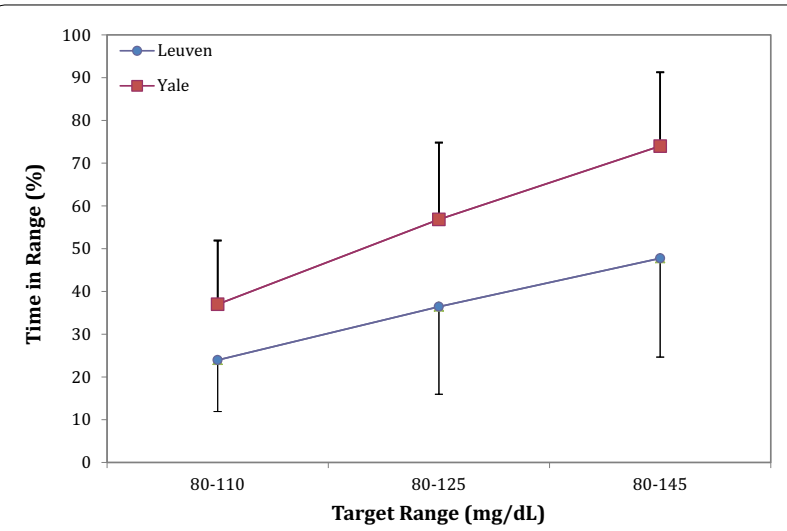

Fig. 1 Average percentage time in range and SD over the groups (Yale vs. Leuven) for the different glycemia target ranges. $P<0.0001$ for all three ranges

strict glycemic control. Logistic regression analysis could not identify type of IIP, diabetes status, age, BMI, or APACHE-II score as independent parameters for strict glucose control. The only parameter which showed an independent association with strict glucose control was the administration of glucocorticoids $(p=0.001)$.

\section{Characteristics of diabetic versus non-diabetic subjects}

No differences in patient demographics except for BMI $(p=0.02)$, in reason for admission, severity of illness, and clinical interventions used, were present between diabetic $(n=21)$ and non-diabetic critically ill patients (Table 3). There were more diabetic patients in the Leuven protocol $(p=0.009)$. Diabetic subjects required more insulin, had a worse median glycemia (131[110-166] vs. $116[107-128] \mathrm{mg} / \mathrm{dl}, p=0.034)$, spent less time in target glycemia ( $25 \pm 12$ vs. $36 \pm 15 \%, p=0.006)$, more time in hypoglycemia $(4[1-10]$ vs. $0[0-1] \%, p=0.001)$ than non-diabetic subjects. All other glucometrics, including glycemic variability parameters, were worse as well in diabetic patients (see Table 3).

In the non-diabetic group, patients in the Yale protocol spent more time in target glycemia ( $40 \pm 15$ vs. $25 \pm 10 \%$, $p=0.009)$, less time in hypoglycemia $(0[0-0]$ vs. $1[0-$ $6] \%, p=0.013)$, and glycemic variability tended to be smaller (SD $p=0.076, \mathrm{CV} p=0.057$, MODD $p=0.021$ ) than those treated by the Leuven protocol. Median glycemia was similar (117[108-127] vs. 115[101-140]) in both groups (Additional file 1: Table S1). In the diabetic subjects, insulin needs were lower $(p=0.044)$ and patients spent less time at a glycemia $>150 \mathrm{mg} / \mathrm{dl}(26 \pm 21$ vs. $35 \pm 25 \%, p=0.003)$ in the Yale compared to the Leuven group. However, median glycemia (120[108-140] vs. 136[111-169] mg/dl), time spent in hypoglycemia or at target range, and parameters of glycemic variability were similar between groups (Additional file 1: Table S1).

\section{Discussion}

Achieving strict glycemic control without risk of hypoglycemia in the ICU is difficult. It requires a comprehensive and safe insulin infusion protocol (IIP) that is both detailed enough and practical enough to be easily implemented by ICU nurses [2, 28]. Multiple IIPs have been developed, but to the best of our knowledge this is the first study comparing the clinical efficacy (\% time in target glycemia) and safety (hypoglycemia, glycemic variability) of two IIPs in MICU patients by means of CGM. Overall, compared to existing data (see Table 4, [3-15, 29-38], both our IIPs were able to obtain reasonably strict glucose control without excessive risk of hypoglycemia. The percentage of time in normoglycemia was higher (37 vs. $26 \%$ ), and percentage of time in hypoglycemia lower (0 vs. $5 \%)$ and glycemic variability was less pronounced in patients treated with the Yale IIP. Diabetes status can, however, be a confounding factor [34]. We 


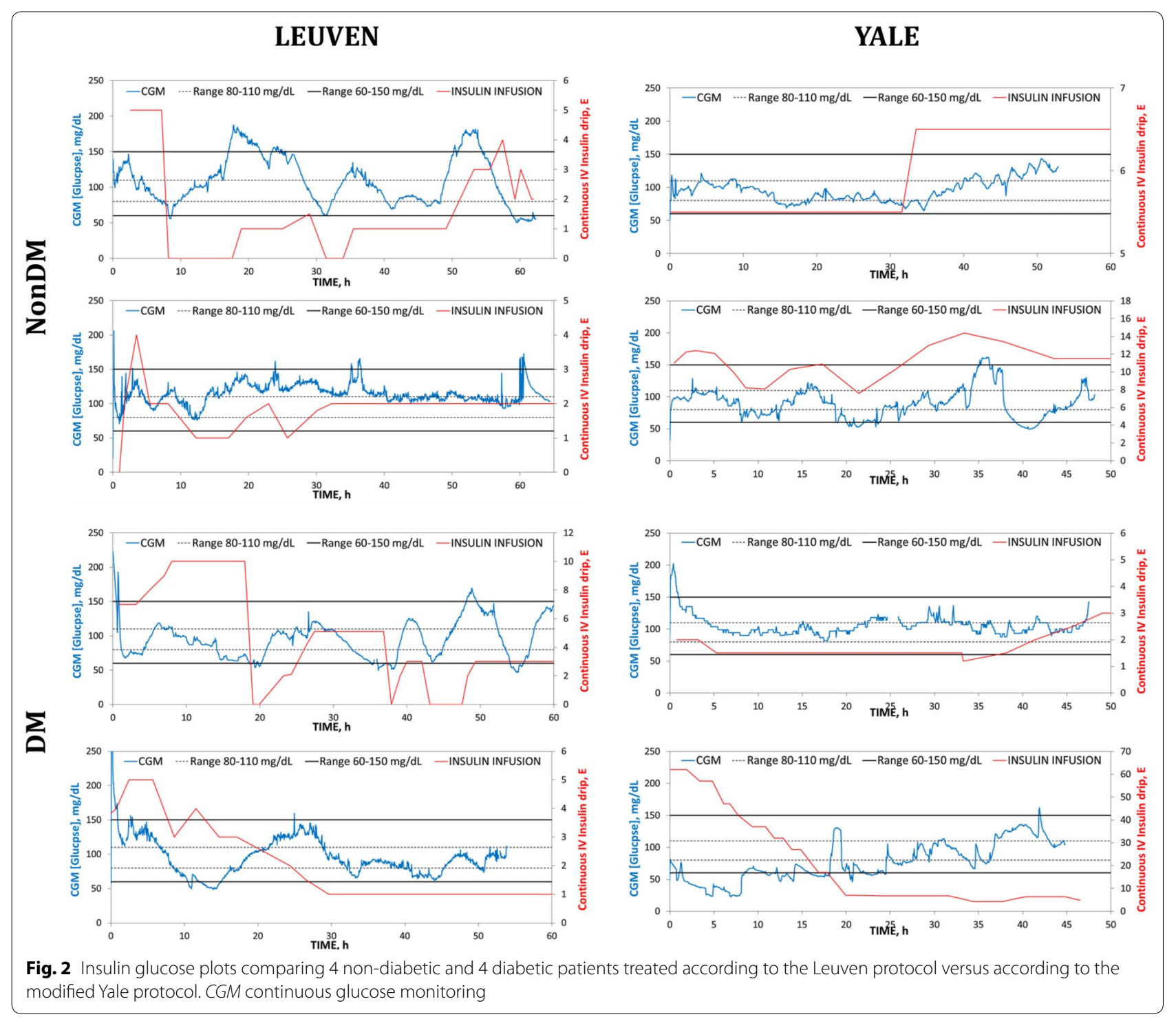

observed an imbalance in the number of diabetic subjects with more diabetic patients in the Leuven group. Diabetic as compared to non-diabetic subjects required more insulin, had worse glycemic control, and larger glycemic variability, thereby possibly blunting the effect of the IIP. However, logistic regression could not identify type of IIP, diabetes status, or severity of illness as independent parameters associated with strict glucose control. When comparing Yale versus Leuven protocol in non-diabetic subjects, patients in the Yale protocol had better glucometrics. This was evident, despite the low number of patients. In the diabetic subgroup, however, the advantages of the Yale protocol were less pronounced.

Up till now no single IIP has been established as the most effective for obtaining tight glycemic control
$[28,39,40]$. The IIP should be tailored to the subset of patients being treated and to local resources, because an excellent validated IIP is no guarantee for optimal glucose control unless it is carefully implemented. Most IIPs show significant similarities, but differences relate to target glucose levels $(80-110 \mathrm{mg} / \mathrm{dl}$ versus ranges varying between 90 and $180 \mathrm{mg} / \mathrm{dl}$ ), initial glycemic threshold ( $>150-200 \mathrm{mg} / \mathrm{dl}$ ), infusion rates, use of boluses, and frequency of monitoring. Changes in insulin infusion rate may relate to actual glycemia, direction and/or velocity of change in glycemia, degree of insulin resistance, and insulin dose. The population treated (surgical vs. medical ICU, diabetes status) may also affect the performance of the IIP $[2,28,39,40]$. The competence of the nurses and clarity of instructions also influence outcome. 
Table 2 Baseline characteristics, interventions used and glucometrics of patients reaching an average glycemia $\leq 110 \mathrm{mg} / \mathrm{dl}$ versus those with an average glycemia $>110 \mathrm{mg} / \mathrm{dl}$

\begin{tabular}{|c|c|c|c|}
\hline & Avg glyc $\leq 110 \mathrm{mg} / \mathrm{dl}$ & Avg glyc $>110 \mathrm{mg} / \mathrm{dl}$ & Statistics \\
\hline Number of patients & 19 & 38 & \\
\hline \multicolumn{4}{|l|}{ Patient demographics } \\
\hline Men/women & $8 / 11$ & $22 / 16$ & NS \\
\hline Diabetic status (no/type1/type2) & $14 / 1 / 4$ & $23 / 4 / 11$ & NS \\
\hline Age (years) & $65 \pm 11$ & $63 \pm 12$ & NS \\
\hline $\mathrm{BMI}\left(\mathrm{kg} / \mathrm{m}^{2}\right)$ & $26.3 \pm 3.8$ & $27.1 \pm 6.1$ & NS \\
\hline \multicolumn{4}{|l|}{ Severity of illness } \\
\hline APACHE-II score & $27 \pm 6$ & $28 \pm 7$ & NS \\
\hline SOFA score & $10 \pm 4$ & $10 \pm 3$ & NS \\
\hline \multicolumn{4}{|l|}{ Clinical interventions } \\
\hline Mechanical ventilation & 14 & 31 & NS \\
\hline Vasopressor therapy & 12 & 23 & NS \\
\hline Hemodialysis & 5 & 9 & NS \\
\hline No/total parenteral/enteral feeding & $4 / 6 / 9$ & $13 / 11 / 14$ & NS \\
\hline Glucocorticoids & 15 & 12 & 0.01 \\
\hline Antibiotics & 17 & 29 & NS \\
\hline Protocol (Leuven/Yale) & $7 / 12$ & $15 / 23$ & NS \\
\hline \multicolumn{4}{|l|}{ Insulin dose } \\
\hline Day 1 (units) & $62(33-133)$ & $63(39-128)$ & NS \\
\hline Day 2 (units) & $67(23-101)$ & $70(42-120)$ & NS \\
\hline \multicolumn{4}{|l|}{ Glucose parameters } \\
\hline $\mathrm{HbA1c}(\%)$ & $6.1(5.6-6.7)$ & $6.0(5.8-6.9)$ & NS \\
\hline $\mathrm{HbA1c}(\mathrm{mmol} / \mathrm{mol})$ & $43(38-50)$ & $70(42-120)$ & NS \\
\hline Median glycemia (mg/dl) & $104(100-108)$ & $128(119-141)$ & $<0.0001$ \\
\hline \multicolumn{4}{|l|}{$\%$ of time at glycemia } \\
\hline$<60 \mathrm{mg} / \mathrm{dl}$ & $5(0-8)$ & $0(0-4)$ & 0.067 \\
\hline $80-110 \mathrm{mg} / \mathrm{dl}$ & $41 \pm 14$ & $27 \pm 13$ & 0.001 \\
\hline$>150 \mathrm{mg} / \mathrm{dl}$ & $6 \pm 6$ & $28 \pm 18$ & $<0.0001$ \\
\hline$>200 \mathrm{mg} / \mathrm{dl}$ & $1 \pm 2$ & $10 \pm 16$ & 0.017 \\
\hline $60-150 \mathrm{mg} / \mathrm{dl}$ & $89 \pm 11$ & $69 \pm 19$ & $<0.0001$ \\
\hline $70-180$ mg/dl & $86 \pm 14$ & $80 \pm 19$ & NS \\
\hline Nr of art blood glc measurements/day & $10 \pm 3$ & $10 \pm 4$ & NS \\
\hline \multicolumn{4}{|l|}{ Glucose variability parameters } \\
\hline $\mathrm{SD}(\mathrm{mg} / \mathrm{dl})$ & $25(20-36)$ & $38(29-63)$ & 0.003 \\
\hline Coefficient of variation (\%) & $25(20-33)$ & $29(23-44)$ & NS \\
\hline IQR & $33(27-55)$ & $45(35-76)$ & 0.031 \\
\hline MAGE (mg/dl) & $50(34-72)$ & $60(43-100)$ & 0.085 \\
\hline MODD (mg/dl) & $29(22-45)$ & $42(32-76)$ & 0.005 \\
\hline M-100 & $2(1-4)$ & $6(4-14)$ & 0.001 \\
\hline CONGA1 (mg/dl) & $15(12-19)$ & $21(15-35)$ & 0.008 \\
\hline CONGA2 (mg/dl) & $22(17-28)$ & $32(20-48)$ & 0.010 \\
\hline CONGA4 (mg/dl) & $29(18-43)$ & $42(27-69)$ & 0.011 \\
\hline LBGI & $2.7(0.9-3.8)$ & $0.7(0.2-1.9)$ & 0.001 \\
\hline HBGI & $0.3(0.2-1.1)$ & $2.0(1.4-4.5)$ & $<0.0001$ \\
\hline Glucose variability & $21(17-28)$ & $36(29-53)$ & $<0.0001$ \\
\hline
\end{tabular}

Data are presented as numbers, as mean \pm SD or median (25-75th percentile)

LOS in ICU length of stay in ICU, IQR interquartile range, MAGE mean amplitude of glycemic excursions, MODD mean of daily differences, $L B G I$ low blood glucose index, $H B G$ high BGI 
Table 3 Baseline characteristics, interventions used and glucometrics of non-diabetic versus diabetic patients

\begin{tabular}{|c|c|c|c|}
\hline & Non-DM & DM & Statistics \\
\hline Number of patients & 36 & 21 & \\
\hline \multicolumn{4}{|l|}{ Patient demographics } \\
\hline Men/women & $19 / 17$ & $11 / 10$ & NS \\
\hline Age (years) & $65 \pm 11$ & $62 \pm 12$ & NS \\
\hline $\mathrm{BMI}\left(\mathrm{kg} / \mathrm{m}^{2}\right)$ & $26 \pm 4$ & $29 \pm 7$ & 0.02 \\
\hline \multicolumn{4}{|l|}{ Severity of illness } \\
\hline APACHE-II score & $29 \pm 6$ & $26 \pm 7$ & NS \\
\hline SOFA score & $11 \pm 4$ & $9 \pm 3$ & NS (0.064) \\
\hline \multicolumn{4}{|l|}{ Clinical interventions } \\
\hline Mechanical ventilation & 27 & 17 & NS \\
\hline Vasopressor therapy & 23 & 12 & NS \\
\hline Hemodialysis & 12 & 2 & NS (0.06) \\
\hline $\begin{array}{l}\text { No/total parenteral/enteral } \\
\text { feeding }\end{array}$ & $7 / 13 / 16$ & $10 / 4 / 7$ & NS (0.075) \\
\hline Glucocorticoids & 20 & 7 & NS \\
\hline Antibiotics & 30 & 16 & NS \\
\hline Protocol (Leuven/Yale) & $9 / 27$ & $13 / 8$ & 0.009 \\
\hline \multicolumn{4}{|l|}{ Insulin dose } \\
\hline Day 1 (units) & $48(26-82)$ & $127(51-175)$ & 0.001 \\
\hline Day 2 (units) & $46(25-85)$ & $113(67-168)$ & 0.009 \\
\hline \multicolumn{4}{|l|}{ Glucose parameters } \\
\hline $\mathrm{HbA1c}(\%)$ & $5.9(5.6-6.3)$ & $6.9(6.1-7.3)$ & $<0.0001$ \\
\hline $\mathrm{HbA1c}(\mathrm{mmol} / \mathrm{mol})$ & $41(38-45)$ & $52(43-56)$ & $<0.0001$ \\
\hline Median glycemia (mg/dl) & $116(107-128)$ & $131(110-166)$ & 0.034 \\
\hline \multicolumn{4}{|l|}{$\%$ of time at glycemia } \\
\hline$<60 \mathrm{mg} / \mathrm{dl}$ & $0(0-1)$ & $4(1-10)$ & 0.001 \\
\hline $80-110 \mathrm{mg} / \mathrm{dl}$ & $36 \pm 15$ & $25 \pm 12$ & 0.006 \\
\hline$>150 \mathrm{mg} / \mathrm{dl}$ & $32 \pm 15$ & $24 \pm 11$ & 0.001 \\
\hline$>200 \mathrm{mg} / \mathrm{dl}$ & $3 \pm 15$ & $15 \pm 20$ & 0.001 \\
\hline $60-150 \mathrm{mg} / \mathrm{dl}$ & $83 \pm 12$ & $63 \pm 23$ & $<0.0001$ \\
\hline $70-180 \mathrm{mg} / \mathrm{dl}$ & $90 \pm 11$ & $69 \pm 19$ & $<0.0001$ \\
\hline $\begin{array}{l}\mathrm{Nr} \text { of art blood glc } \\
\text { measurements/day }\end{array}$ & $10 \pm 4$ & $10 \pm 3$ & NS \\
\hline \multicolumn{4}{|l|}{$\begin{array}{l}\text { Glucose variability } \\
\text { parameters }\end{array}$} \\
\hline $\mathrm{SD}(\mathrm{mg} / \mathrm{dl})$ & $28(21-35)$ & $53(40-75)$ & $<0.0001$ \\
\hline Coefficient of variation (\%) & $23(19-30)$ & $38(29-51)$ & $<0.0001$ \\
\hline IQR & $38(28-45)$ & $66(41-108)$ & $<0.0001$ \\
\hline MAGE (mg/dl) & $49(35-66)$ & $87(56-127)$ & 0.002 \\
\hline $\operatorname{MODD}(\mathrm{mg} / \mathrm{dl})$ & $35(26-42)$ & $59(35-116)$ & $<0.0001$ \\
\hline$M-100$ & $4(2-5)$ & $12(6-29)$ & $<0.0001$ \\
\hline CONGA1 (mg/dl) & $15(13-20)$ & $30(19-41)$ & $<0.0001$ \\
\hline CONGA2 (mg/dl) & $22(17-30)$ & $44(26-59)$ & $<0.0001$ \\
\hline CONGA4 (mg/dl) & $30(21-43)$ & $60(37-86)$ & $<0.0001$ \\
\hline LBGI & $0.7(0.3-1.8)$ & $2.3(0.9-3.7)$ & 0.013 \\
\hline $\mathrm{HBGl}$ & $1.2(0.4-1.8)$ & $3.0(1.4-10.3)$ & 0.002 \\
\hline Glucose variability & $28(20-34)$ & $44(34-79)$ & $<0.0001$ \\
\hline
\end{tabular}

Data are presented as numbers, as mean \pm SD or median (25-75th percentile) LOS in ICU length of stay in ICU, IQR interquartile range, MAGE mean amplitude of glycemic excursions, $M O D D$ mean of daily differences, $L B G$ l low blood glucose index, $H B G$ / high BGI
Computerized decision-supported algorithms might provide superior glucose control compared to paper-based IIPs because of reduced errors by enabling the use of complex mathematical calculations and better protocol consistency. In MICUs and mixed ICUs where a glycemia between 80 and $110 \mathrm{mg} / \mathrm{dl}$ was targeted, $22-60 \%$ of all blood glucose values were reported to be in target for paper-based IIPs [3-14], compared to a higher percentage (42-69\%) for computerized IIPs [4, 10, 11, 14, 15] (Additional file 1: Digital Content-Table S1). In contrast, in a before-after study in 192 surgical ICU patients, Barletta et al. [29] could not observe significant glucometric differences between the computer-assisted versus paperbased IIP. It is probably not the paper or computer that makes the largest difference; but the IIP algorithm itself and the competence of the staff.

A head-to-head comparison of different IIPs on glycemic control has only been performed in RCTs in cardiac surgery. Blaha et al. [18] compared two paper protocols with a computerized IIP in 120 patients, showing that the computerized IIP provided better average glucose control, but with a longer time in hypoglycemia risk range than the paper protocols. Dumont and Bourguignon [19] compared the effect of a computerized (EndoTool) versus a paper IIP (modified Portland protocol) in 300 ICU patients, showing better glucose control and nurses' satisfaction with the EndoTool IIP. In both studies, however, it was not only the protocol that differed but also the way it was implemented (paper vs. computerized), making it difficult to assess the true value of the protocol itself.

Measurement frequency is an inherent part of an IIP and will affect glucometrics. Recently, the effect of the IIP (Yale vs. University of Washington), frequency of glucose measurements (hourly vs. every $5 \mathrm{~min}$ ), and measurement imprecision on glycemic control efficacy was studied using a simulation model [16]. In both IIPs, the rates of hypo- and hyperglycemia and of glycemic variability increased with increasing measurement imprecision. Others investigated the performance of the IIP versus methodology of glucose measurements (blood glucose meter vs. CGM) at different levels of measurement accuracy [17]. The protocol itself proved to have a greater effect on glycemic control efficacy than the glucose measurement method, with the Yale protocol showing the best performance. However, hypoglycemia risk was lower in CGMinformed IIPs [17]. Thus, efficacy of the IIP together with performance and accuracy of the CGM device used both contribute to the success of tight glucose control. In the future, validated computerized IIPs can be guided by realtime CGM in a semi-closed loop, thereby improving efficacy, safety and reducing nursing workload.

Comparison of glucometrics between studies using different IIPs is difficult due to differences in population, 
Table 4 Summary of several insulin infusion protocols in different ICU settings

\begin{tabular}{|c|c|c|c|c|c|c|c|}
\hline Authors & ICU type & Study & $n$ & $\begin{array}{l}\% \text { Diabetic } \\
\text { patients }\end{array}$ & Protocol & $\begin{array}{l}\text { Target glycemia } \\
(\mathrm{mg} / \mathrm{dl})\end{array}$ & $\begin{array}{l}\text { Method of glucose } \\
\text { measurements }\end{array}$ \\
\hline $\begin{array}{l}\text { Goldberg et al. } \\
\text { (2004) }\end{array}$ & MICU & Observational & 52 & 56 & Yale & 100-139 & $\begin{array}{l}\text { Hospital glucose } \\
\text { meter: near hourly } \\
\text { measurements }\end{array}$ \\
\hline $\begin{array}{l}\text { Van den Berghe } \\
\text { et al. (2006) }\end{array}$ & $\mathrm{MICU}$ & $\mathrm{RCT}$ & 1200 & 17 & Paper: Leuven & $80-110$ & ABG: q1-4h \\
\hline Kulnik et al. (2008) & $\mathrm{MICU}$ & Observational & 10 & 20 & eMPC (computer) & $80-110$ & $\begin{array}{l}\text { Variable sampling } \\
\text { rate: q20 min-4 h }\end{array}$ \\
\hline Shetty et al. (2012) & MICU & Observational & 90 & 66 & Yale & $120-160$ & $\begin{array}{l}\text { POC meter: hourly } \\
\text { measurements }\end{array}$ \\
\hline $\begin{array}{l}\text { Holzinger et al. } \\
\text { (2010) }\end{array}$ & $\mathrm{MICU}$ & $\mathrm{RCT}$ & 124 & 19 & Leuven & $80-110$ & CGM \\
\hline $\begin{array}{l}\text { De Block et al. } \\
\text { (2015) }\end{array}$ & MICU & $\mathrm{RCT}$ & 35 & 23 & Yale & $80-110$ & CGM \\
\hline Finney et al. (2003) & Mixed & Observational & 523 & 16 & Paper & $90-145$ & $A B G$ \\
\hline Juneja et al. (2007) & Mixed & Observational & 2398 & NR & $\begin{array}{l}\text { Clarian Gluco } \\
\text { Stabilizer }\end{array}$ & $80-110$ & POC: q1-2h \\
\hline Chase et al. (2008) & Mixed & Observational & 371 & 17 & SPRINT & $80-110$ & $\begin{array}{l}\text { Sampling rate: } \\
\text { q1-2 } \mathrm{h}\end{array}$ \\
\hline Morris et al. (2008) & Mixed & Before-after & 755 & NR & $\begin{array}{l}\text { eProtocol-insulin } \\
\text { versus paper }\end{array}$ & $80-110$ & POC: q1-4 h \\
\hline $\begin{array}{l}\text { Preiser et al. GLU- } \\
\text { CONTROL (2009) }\end{array}$ & Mixed & $\mathrm{RCT}$ & 1078 & 21 & Paper: glucontrol & $80-110$ & POC: q1-4h \\
\hline NICE SUGAR (2009) & Mixed & $\mathrm{RCT}$ & 6104 & 20 & Paper: Leuven & $81-108$ & $A B G$ \\
\hline Marvin et al. (2013) & Mixed & Retrospective & 1657 & NR & Computerized Yale & $100-140$ & $\begin{array}{l}\text { POC: variable time } \\
\text { interval }\end{array}$ \\
\hline $\begin{array}{l}\text { Van Herpe et al. } \\
\text { (2013) }\end{array}$ & Mixed & $\mathrm{RCT}$ & 300 & 21 & $\begin{array}{l}\text { LOGIC-insulin } \\
\text { computerized }\end{array}$ & $80-110$ & $\begin{array}{l}\text { ABG: variable time } \\
\text { interval: q1-4 h }\end{array}$ \\
\hline Krinsley et al. (2015) & Mixed & Retrospective & 3297 & 23 & Paper: Stamford & $70-140$ & POC: q3 h \\
\hline $\begin{array}{l}\text { Vogelzang et al. } \\
\text { (2005) }\end{array}$ & SICU & Observational & 179 & 15 & GRIP & $72-135$ & $\begin{array}{l}\text { POC blood gas ana- } \\
\text { lyzer: variable }\end{array}$ \\
\hline Plank et al. (2006) & $\begin{array}{l}\text { SICU: cardiotho- } \\
\text { racic surgery }\end{array}$ & $\mathrm{RCT}$ & 60 & 23 & eMPC versus paper & $80-110$ & $\begin{array}{l}\text { POC: variable sam- } \\
\text { pling rate: } q 1 \mathrm{~h}-4 \mathrm{~h}\end{array}$ \\
\hline $\begin{array}{l}\text { Hovorka et al. } \\
(2007)\end{array}$ & $\begin{array}{l}\text { SICU: cardiac } \\
\text { surgery }\end{array}$ & $\mathrm{RCT}$ & 60 & 45 & eMPC & $80-110$ & $\begin{array}{l}\text { Variable sampling } \\
\text { rate: } \mathrm{q} 1 \mathrm{~h}-4 \mathrm{~h}\end{array}$ \\
\hline Saager et al. (2008) & $\begin{array}{l}\text { SICU: cardiotho- } \\
\text { racic ICU }\end{array}$ & $\mathrm{RCT}$ & 40 & 100 & $\begin{array}{l}\text { EndoTool (com- } \\
\text { puter) versus } \\
\text { paper }\end{array}$ & $90-150$ & POC: hourly \\
\hline Dortch et al. (2008) & SICU: trauma ICU & $\mathrm{RCT}$ & 552 & & $\begin{array}{l}\text { Computer versus } \\
\text { paper }\end{array}$ & $80-110$ & POC q1-4h \\
\hline Blaha et al. (2009) & $\begin{array}{l}\text { SICU: cardiac } \\
\text { surgery }\end{array}$ & $\mathrm{RCT}$ & 120 & 14 & $\begin{array}{l}\text { eMPC versus paper } \\
\text { (Matias versus } \\
\text { Bath) }\end{array}$ & $80-110$ & $\begin{array}{l}\text { ABG: protocol } \\
\text { dependent: q1-4 } \mathrm{h}\end{array}$ \\
\hline Barletta et al. (2011) & SICU & Before-after & 192 & 28 & $\begin{array}{l}\text { Computer versus } \\
\text { paper }\end{array}$ & $80-110$ & $\begin{array}{l}\text { POC: variable } \\
\text { sampling rate: } \\
\text { q30 min-2 h versus } \\
\text { q2 h }\end{array}$ \\
\hline $\begin{array}{l}\text { Dumont et al. } \\
(2012)\end{array}$ & $\begin{array}{l}\text { SICU: cardiovascu- } \\
\text { lar ICU }\end{array}$ & $\mathrm{RCT}$ & 300 & 43 & $\begin{array}{l}\text { Computer (Endo- } \\
\text { Tool) versus } \\
\text { paper (modified } \\
\text { Portland) }\end{array}$ & $80-150$ & NA \\
\hline
\end{tabular}


Table 4 continued

\begin{tabular}{|c|c|c|c|c|c|c|c|}
\hline Authors & $\begin{array}{l}\text { Duration of glu- } \\
\text { cose monitoring }\end{array}$ & $\begin{array}{l}\text { Glucometric } \\
\text { to measure } \\
\text { target }\end{array}$ & $\begin{array}{l}\text { \% of time at tar- } \\
\text { get glycemia: } \\
\text { intervention } \\
\text { versus control } \\
\text { group }\end{array}$ & $\begin{array}{l}\text { Mean glyce- } \\
\text { mia (mg/dl): } \\
\text { intervention } \\
\text { versus control } \\
\text { group }\end{array}$ & $\begin{array}{l}\text { Hypoglycemia: } \\
\text { intervention } \\
\text { versus control } \\
\text { group }\end{array}$ & $\begin{array}{l}\text { Glycemic vari- } \\
\text { ability }\end{array}$ & References \\
\hline $\begin{array}{l}\text { Goldberg et al. } \\
\text { (2004) }\end{array}$ & $61 \mathrm{~h}$ & $\begin{array}{l}\text { Percent of hourly } \\
\text { BG values in } \\
\text { target range }\end{array}$ & $52 \%$ & $124 \pm 15$ & $\begin{array}{l}\% \text { of data at glc } \\
\quad<60 \mathrm{mg} / \mathrm{dl}: \\
0.3 \%\end{array}$ & NA & {$[8]$} \\
\hline $\begin{array}{l}\text { Van den Berghe } \\
\text { et al. (2006) }\end{array}$ & NR & $\begin{array}{l}\text { Mean morning } \\
\text { BG }\end{array}$ & NA & $\begin{array}{l}111 \pm 29 \text { versus } \\
153 \pm 31\end{array}$ & $\begin{array}{l}\text { \% of patients: glc } \\
\quad<40 \mathrm{mg} / \mathrm{dl}: 18.7 \\
\text { versus } 3.1 \%\end{array}$ & NA & [13] \\
\hline $\begin{array}{l}\text { Kulnik et al. } \\
\text { (2008) }\end{array}$ & $72 \mathrm{~h}$ & $\begin{array}{l}\text { Percent of BG } \\
\text { values in target }\end{array}$ & $47 \pm 13 \%$ & $109 \pm 13$ & $\begin{array}{l}\% \text { data at glc } \\
\quad<40 \mathrm{mg} / \mathrm{dl}: 0 \%\end{array}$ & NA & [15] \\
\hline $\begin{array}{l}\text { Shetty et al. } \\
\text { (2012) }\end{array}$ & $59 \mathrm{~h}$ & $\begin{array}{l}\text { Percent of BG } \\
\text { values in target } \\
\text { range }\end{array}$ & $42 \%$ & $156 \pm 23$ & $\begin{array}{l}\text { \% of data } \\
\quad<70 \mathrm{mg} / \mathrm{dl}: \\
0.3 \%\end{array}$ & NA & [37] \\
\hline $\begin{array}{l}\text { Holzinger et al. } \\
\text { (2010) }\end{array}$ & $72 \mathrm{~h}$ & $\begin{array}{l}\text { CGM data: per- } \\
\text { cent of data in } \\
\text { target range }\end{array}$ & $\begin{array}{l}59 \pm 20 \text { versus } \\
55 \pm 18\end{array}$ & $\begin{array}{l}106 \pm 18 \text { versus } \\
111 \pm 10\end{array}$ & $\begin{array}{l}\text { Rate: } 1.9 \% \text { versus } \\
\quad 11.5 \%\end{array}$ & NA & [9] \\
\hline $\begin{array}{l}\text { De Block et al. } \\
\text { (2015) }\end{array}$ & $96 \mathrm{~h}$ & $\begin{array}{l}\text { CGM data: per- } \\
\text { cent of data in } \\
\text { target range }\end{array}$ & $\begin{array}{l}37 \pm 12 \text { versus } \\
34 \pm 10\end{array}$ & $\begin{array}{l}119 \pm 17 \text { versus } \\
122 \pm 11\end{array}$ & $\begin{array}{l}\% \text { of time at glc } \\
\quad<60 \mathrm{mg} / \mathrm{dl} \text { : } \\
0.6 \pm 1.6 \text { versus } \\
2.4 \pm 4.3 \%\end{array}$ & $\begin{array}{l}\text { No differences } \\
\text { between } \\
\text { groups in SD, } \\
\text { MAGE, MODD, } \\
\text { CV }\end{array}$ & {$[6]$} \\
\hline $\begin{array}{l}\text { Finney et al. } \\
\text { (2003) }\end{array}$ & $22-89 h$ & $\begin{array}{l}\text { Time spent in } \\
\text { glucose band } \\
80-110 \mathrm{mg} / \mathrm{dl}\end{array}$ & $4(0-20) \%$ & NR & $0 \pm 1 \%$ & NA & [31] \\
\hline $\begin{array}{l}\text { Juneja et al. } \\
\text { (2007) }\end{array}$ & NR & $\begin{array}{l}\text { Percent of data in } \\
\text { target range }\end{array}$ & 52 versus 32\% & $107 \pm 39$ & $\begin{array}{l}\% \text { data at glc } \\
\quad<50 \mathrm{mg} / \mathrm{dl}: 0.4 \\
\text { versus } 0.5 \%\end{array}$ & NA & [10] \\
\hline $\begin{array}{l}\text { Chase et al. } \\
(2008)\end{array}$ & $53 \mathrm{~h}$ & $\begin{array}{l}\text { Percent of BG } \\
\text { values in target }\end{array}$ & $54 \%$ & $108 \pm 27$ & $\begin{array}{l}\% \text { of data at glc } \\
\quad<72 \mathrm{mg} / \mathrm{dl}: \\
3.8 \%\end{array}$ & SD: $27 \mathrm{mg} / \mathrm{dl}$ & {$[4]$} \\
\hline $\begin{array}{l}\text { Morris et al. } \\
\text { (2008) }\end{array}$ & 4-22 days & $\begin{array}{l}\text { Percent of BG } \\
\text { values in target }\end{array}$ & 42 versus $28 \%$ & 116 versus 134 & $\begin{array}{l}\% \text { data at glc } \\
<40 \mathrm{mg} / \mathrm{dl}: 11.1 \\
\text { versus } 5.1 \%\end{array}$ & NA & {$[11]$} \\
\hline $\begin{array}{l}\text { Preiser et al. } \\
\text { GLUCONTROL } \\
\text { (2009) }\end{array}$ & $\begin{array}{l}48-216 \mathrm{~h} \\
\quad(=2-9 \text { days })\end{array}$ & $\begin{array}{l}\text { Proportion of } \\
\text { time of BG val- } \\
\text { ues in range }\end{array}$ & $43 \%$ & $\begin{array}{c}117 \text { (IQR: 108- } \\
130) \mathrm{mg} / \mathrm{dl}\end{array}$ & $\begin{array}{l}\text { Proportion of } \\
\text { time at glc } \\
\quad<40 \mathrm{mg} / \mathrm{dl} \text { : } \\
5.9 \pm 27 \%\end{array}$ & SD: 36 mg/dl & [12] \\
\hline $\begin{array}{l}\text { NICE SUGAR } \\
(2009)\end{array}$ & $\begin{array}{l}4.2 \text { days } \\
\quad(1.9-9.0 \text { days })\end{array}$ & $\begin{array}{l}\text { Time-weighted } \\
\text { mean BG }\end{array}$ & NR & $\begin{array}{l}115 \pm 18 \text { versus } \\
144 \pm 23\end{array}$ & $\begin{array}{l}\% \text { of patients: glc } \\
\quad<40 \mathrm{mg} / \mathrm{dl}: 6.8 \\
\text { versus } 0.5 \%\end{array}$ & NA & {$[7]$} \\
\hline $\begin{array}{l}\text { Marvin et al. } \\
\text { (2013) }\end{array}$ & NR & $\begin{array}{l}\text { Percent of hourly } \\
\text { BG values in } \\
\text { target range }\end{array}$ & $92 \%$ & 124 & $\begin{array}{l}\text { \% of data } \\
40-70 \mathrm{mg} / \\
\text { dl: } 1.1 \% \text { and } \\
\text { in } 17.6 \% \text { of } \\
\text { patients }\end{array}$ & NA & {$[34]$} \\
\hline $\begin{array}{l}\text { Van Herpe et al. } \\
\text { (2013) }\end{array}$ & $26-113 \mathrm{~h}$ & $\begin{array}{l}\text { Percent of BG } \\
\text { values in target } \\
\text { range }\end{array}$ & $\begin{array}{l}69 \pm 17 \text { versus } \\
60 \pm 19\end{array}$ & $\begin{array}{l}106 \pm 9 \text { versus } \\
107 \pm 11\end{array}$ & $\begin{array}{l}\% \text { data at glc } \\
<60 \mathrm{mg} / \mathrm{dl}: 0.6 \\
\text { versus 1.2\% }\end{array}$ & $\begin{array}{l}\text { Max change in } \\
\text { glc/24 h: } 31 \\
\text { versus } 37 \mathrm{mg} / \\
\text { dl }\end{array}$ & [14] \\
\hline $\begin{array}{l}\text { Krinsley et al. } \\
\text { (2015) }\end{array}$ & $36-120 h$ & $\begin{array}{l}\text { Percent of time } \\
\text { of } B G \text { values in } \\
\text { target range }\end{array}$ & $\begin{array}{l}\text { Non-DM versus } \\
\text { DM: } 81 \text { (61-94) } \\
\text { versus } 55 \\
(35-71) \%\end{array}$ & $\begin{array}{l}\text { Non-DM versus } \\
\text { DM: } 121 \text { (112- } \\
\text { 133) versus } \\
140 \text { (128-155) } \\
\text { mg/dl }\end{array}$ & $\begin{array}{l}\text { \% of patients: } \\
\text { glc }<70 \mathrm{mg} / \mathrm{dl} \text { : } \\
\text { non-DM versus } \\
\text { DM: } 18 \text { versus } \\
31 \%\end{array}$ & $\begin{array}{l}\text { CV: non-DM } \\
\text { versus DM: } 18 \\
\text { versus 27\% }\end{array}$ & [33] \\
\hline $\begin{array}{l}\text { Vogelzang et al. } \\
\text { (2005) }\end{array}$ & $1.6(0.8-4.7)$ days & $\begin{array}{l}\text { Percent of time } \\
\text { of BG values in } \\
\text { target }\end{array}$ & $78(66-88) \%$ & $121(108-135)$ & $\begin{array}{l}\text { \% of patients: glc } \\
\quad<40: 0.6 \% \text {; glc } \\
\quad<63: 11.2 \%\end{array}$ & NA & [38] \\
\hline
\end{tabular}


Table 4 continued

\begin{tabular}{|c|c|c|c|c|c|c|c|}
\hline Authors & $\begin{array}{l}\text { Duration of glu- } \\
\text { cose monitoring }\end{array}$ & $\begin{array}{l}\text { Glucometric } \\
\text { to measure } \\
\text { target }\end{array}$ & $\begin{array}{l}\% \text { of time at tar- } \\
\text { get glycemia: } \\
\text { intervention } \\
\text { versus control } \\
\text { group }\end{array}$ & $\begin{array}{l}\text { Mean glyce- } \\
\text { mia (mg/dl): } \\
\text { intervention } \\
\text { versus control } \\
\text { group }\end{array}$ & $\begin{array}{l}\text { Hypoglycemia: } \\
\text { intervention } \\
\text { versus control } \\
\text { group }\end{array}$ & $\begin{array}{l}\text { Glycemic vari- } \\
\text { ability }\end{array}$ & References \\
\hline Plank et al. (2006) & $48 \mathrm{~h}$ & $\begin{array}{l}\text { Percent of time in } \\
\text { target range }\end{array}$ & $\begin{array}{l}52(17-92) \text { versus } \\
19(0-71) \%\end{array}$ & $\begin{array}{c}117(102-144) \\
\text { versus } 131 \\
(97-237)\end{array}$ & $\begin{array}{l}\text { Number of } \\
\text { hypo episodes } \\
(<54 \mathrm{mg} / \mathrm{dl}) \\
\text { over } 48 \mathrm{h:} 0 \\
\text { versus } 2\end{array}$ & NA & [35] \\
\hline $\begin{array}{l}\text { Hovorka et al. } \\
\text { (2007) }\end{array}$ & $24 \mathrm{~h}$ & $\begin{array}{l}\text { Percent of time in } \\
\text { target range }\end{array}$ & $\begin{array}{l}60 \pm 23 \text { versus } \\
28 \pm 16\end{array}$ & $\begin{array}{l}112 \pm 20 \text { versus } \\
130 \pm 20\end{array}$ & $\begin{array}{l}\% \text { of data at glc } \\
<52 \mathrm{mg} / \mathrm{dl}: 0 \% \\
\text { versus } 0 \%\end{array}$ & NA & [32] \\
\hline $\begin{array}{l}\text { Saager et al. } \\
\text { (2008) }\end{array}$ & $9 \mathrm{~h}$ & $\begin{array}{l}\text { Percent of BG } \\
\text { values in target }\end{array}$ & 84 versus $60 \%$ & $\begin{array}{c}126 \pm 18 \text { versus } \\
147 \pm 27\end{array}$ & $\begin{array}{l}\text { Episodes of hypo } \\
(<60 \mathrm{mg} / \mathrm{dl}) \\
\text { during ICU: } 4 \\
\text { versus } 1\end{array}$ & NA & {$[36]$} \\
\hline $\begin{array}{l}\text { Dortch et al. } \\
\text { (2008) }\end{array}$ & $N R$ & $\begin{array}{l}\text { Percent of BG } \\
\text { values in target }\end{array}$ & 42 versus $34 \%$ & $\begin{array}{c}116 \pm 37 \text { versus } \\
120 \pm 37\end{array}$ & $\begin{array}{l}\% \text { data at glc } \\
\quad<40 \mathrm{mg} / \mathrm{dl}: 0.2 \\
\text { versus } 0.5 \%\end{array}$ & NA & {$[30]$} \\
\hline Blaha et al. (2009) & $45-48 h$ & $\begin{array}{l}\text { Time in target } \\
\text { range }\end{array}$ & $\begin{array}{c}46 \pm 3 \text { versus } \\
38 \pm 3 \text { versus } \\
40 \pm 3 \%\end{array}$ & $\begin{array}{l}106 \pm 4 \text { versus } \\
121 \pm 4 \text { versus } \\
117 \pm 4\end{array}$ & $\begin{array}{l}\text { Time in hypo } \\
(<52 \mathrm{mg} / \mathrm{dl}): \\
0 \pm 0 \text { versus } \\
0.4 \pm 0.2 \text { versus } \\
0.4 \pm 0.3 \%\end{array}$ & NA & [18] \\
\hline $\begin{array}{l}\text { Barletta et al. } \\
\text { (2011) }\end{array}$ & 67 versus $98 \mathrm{~h}$ & $\begin{array}{l}\text { Percent of BG } \\
\text { values in target }\end{array}$ & $\begin{array}{l}49 \pm 14 \text { versus } \\
40 \pm 12\end{array}$ & $\begin{array}{l}113 \pm 11 \text { versus } \\
116 \pm 11\end{array}$ & $\begin{array}{l}\% \text { data at glc } \\
<40 \mathrm{mg} / \mathrm{dl}: 2.1 \\
\text { versus } 4.1 \%\end{array}$ & $\begin{array}{c}\text { SD: } 25 \pm 9 \text { versus } \\
\quad 31 \pm 11 \mathrm{mg} / \mathrm{dl}\end{array}$ & [29] \\
\hline $\begin{array}{l}\text { Dumont et al. } \\
(2012)\end{array}$ & NA & $\begin{array}{l}\text { Percent of BG } \\
\text { values in target } \\
\text { range }\end{array}$ & $\begin{array}{l}70 \pm 15 \text { versus } \\
62 \pm 18\end{array}$ & $\begin{array}{l}138 \pm 16 \text { versus } \\
141 \pm 20\end{array}$ & $\begin{array}{l}\text { Number of hypo } \\
\text { events }<60 \mathrm{mg} / \\
\text { dl: } 7(5 \%) \text { versus } \\
18(11 \%)\end{array}$ & $\begin{array}{l}\text { SD: } 36 \pm 18 \text { ver- } \\
\quad \text { sus } 42 \pm 21\end{array}$ & [19] \\
\hline
\end{tabular}

MICU medical intensive care unit, SICU surgical ICU, RCT randomized controlled trial, NR not reported, NA not assessed, $A B G$ arterial blood glucose, $P O C$ point of care, $S D$ standard deviation

target glycemia, and frequency of glucose monitoring. In addition, many different glucometrics are reported in different studies, including metrics of central tendency (mean or median glycemia, time-averaged glucose, admission glycemia, proportion of glucose values in target), metrics of extremes (percentages or episodes of hypo- or hyperglycemia), and metrics of dispersion (SD, coefficient of variation, MAGE). The robustness of glucometrics depends largely on the number of measurements per time unit used for its calculation. Accurate assessment of time in target glycemia, or in hypo- or hyperglycemia, and of glucose variability can only be done by using validated CGM methodology.

Our study has some limitations and strengths. This is a pooled data analysis of two prospective RCTs conducted at the medical ICUs, using relatively old data. Indeed, patients were recruited between 04/2004 and 03/2005 for the first study and between 07/2007 and 09/2009 for the second study. However, pooling the CGM data is justifiable in our opinion because the same CGM sensor was used in both studies and the study population and standards of care in both services were comparable. However, our results might not be applicable to a mixed or surgical ICU setting. Despite more than 63,000 CGM glucose measurements being available for analysis, due to the small number of patients and heterogeneity of groups, statistical superiority of the Yale protocol could not be proven.

A major strength, in our opinion, when comparing IIPs, is the use of CGM data which provides a complete picture of glucometrics. We did not make use of study nurses particularly focused on glucose control, but implemented our study in a routine clinical setting, allowing a more clinically relevant picture.

In summary, the use of a safe and efficient IIP is a prerequisite to correctly implement strict glycemic targets. Both IIPs have proven to balance efficacy with safety (avoid hypoglycemia and glycemic variability) and attainability (nursing workload). Overall, the modified Yale protocol provided better glucose control with more time spent in normoglycemia, less time spent in hypoglycemia, and less glycemic variability as compared to the Leuven protocol. 


\section{Additional file}

Additional file 1: Table S1. Baseline characteristics and glucometrics of patients treated by the Leuven versus Yale protocol, analysed according to diabetes status.

\section{Abbreviations}

BMI: body mass index; CGM: continuous glucose monitoring; CONGA: continuous overlapping net glycemic; $\mathrm{HBGl}$ : high blood glucose index; ICU: intensive care unit; IIP: insulin infusion protocol; IV: intravenous; LBGI: Iow blood glucose index; MAGE: mean amplitude of glucose excursions; MICU: medical intensive care unit; MODD: mean of daily differences; RCT: randomized controlled trial(s); SD: standard deviation; UZA: Universitair Ziekenhuis Antwerpen (Antwerp University Hospital).

\section{Authors' contributions}

All authors made important intellectual contributions to the conception and analysis of the study. Every author reviewed and provided comments on manuscript drafts and gave final approval of this version to be published. CEMDB was responsible for the final design of the study. CEMDB, PR, and PGJ recruited patients, implemented the study protocol, and acquired data. CS, who was masked for clinical data and treatment arm, analyzed the CGM profiles with patients being coded. CEMDB and TS performed the statistical analysis. CEMDB drafted the manuscript. All authors read and approved the final manuscript.

\section{Author details}

${ }^{1}$ Department of Endocrinology, Diabetology and Metabolism, Faculty of Medicine, Antwerp University Hospital and University of Antwerp, Wilrijkstraat 10, 2650 Edegem, Belgium. ${ }^{2}$ Intensive Care Unit, ZNA, General Hospital Middelheim, Antwerp, Belgium. ${ }^{3}$ Intensive Care Unit, Antwerp University Hospital, University of Antwerp, Edegem, Belgium. ${ }^{4}$ A. Menarini Diagnostics, Scientific and Technology Affairs, Florence, Italy.

\section{Acknowledgements}

We thank Dr. W. Verbrugghe, Dr. J. Gios, Dr. N. Verheyen (Antwerp University Hospital), and Dr. K. Bervoets (Middelheim Hospital) who contributed to patient recruitment. We gratefully acknowledge the nursing staff of the ICU wards in both hospitals, and all patients. The CGM devices (GlucoDayS) and fibers were provided at no charge by A. Menarini Diagnostics (Florence, Italy) The company had no influence on trial design, analysis, or preparation of the manuscript

Part of this study was accepted for oral presentation at the 9th International Conference on Advanced Technologies and Treatments for Diabetes (ATTD 2016, Milan, Italy).

\section{Competing interests}

The authors declare that they have no competing interests.

\section{Availability of data and materials}

The datasets supporting the conclusions of this article will be available in a repository upon publication of the manuscript.

\section{Ethics approval}

The studies were approved by the ethics committees of both hospitals (Middelheim approval no. 2345 and UZA 6/43/211) and conducted in accordance with the amended Declaration of Helsinki.

Received: 8 June 2016 Accepted: 5 November 2016

Published online: 22 November 2016

\section{References}

1. Jacobi J, Bircher N, Krinsley J, Agus M, Braithwaite SS, Deutschman C, et al. Guidelines for the use of an insulin infusion for the management of hyperglycemia in critically ill patients. Crit Care Med. 2012;40(12):3251-76.
2. De Block C, Manuel-y-Keenoy B, Rogiers P, Jorens P, Van Gaal L. Glucose control and use of continuous glucose monitoring in the intensive care unit: a critical review. Curr Diabetes Rev. 2008;4(3):234-44.

3. Brunkhorst FM, Engel C, Bloos F, Meier-Hellmann A, Ragaller M, Weiler N, et al. Intensive insulin therapy and pentastarch resuscitation in severe sepsis. N Engl J Med. 2008;358(2):125-39.

4. Chase JG, Shaw G, Le Compte A, Lonergan T, Willacy M, Wong XW, et al. Implementation and evaluation of the SPRINT protocol for tight glycaemic control in critically ill patients: a clinical practice change. Crit Care. 2008;12(2):R49

5. De Block C, Manuel-Y-Keenoy B, Van Gaal L, Rogiers P. Intensive insulin therapy in the intensive care unit: assessment by continuous glucose monitoring. Diabetes Care. 2006;29(8):1750-6.

6. De Block CE, Gios J, Verheyen N, Manuel-y-Keenoy B, Rogiers P, Jorens PG, et al. Randomized evaluation of glycemic control in the medical intensive care unit using real-time continuous glucose monitoring (REGIMEN Trial). Diabetes Technol Ther. 2015;17(12):889-98

7. Finfer S, Chittock DR, Su SY, Blair D, Foster D, Dhingra V, et al. Intensive versus conventional glucose control in critically ill patients. N Engl J Med. 2009;360(13):1283-97.

8. Goldberg PA, Siegel MD, Sherwin RS, Halickman JI, Lee M, Bailey VA, et al. Implementation of a safe and effective insulin infusion protocol in a medical intensive care unit. Diabetes Care. 2004;27(2):461-7.

9. Holzinger $U$, Warszawska J, Kitzberger R, Wewalka M, Miehsler W, Herkner $\mathrm{H}$, et al. Real-time continuous glucose monitoring in critically ill patients: a prospective randomized trial. Diabetes Care 2010:33(3):467-72.

10. Juneja R, Roudebush C, Kumar N, Macy A, Golas A, Wall D, et al. Utilization of a computerized intravenous insulin infusion program to control blood glucose in the intensive care unit. Diabetes Technol Ther. 2007:9(3):232-40.

11. Morris AH, Orme J Jr, Truwit JD, Steingrub J, Grissom C, Lee KH, et al. A replicable method for blood glucose control in critically ill patients. Crit Care Med. 2008;36(6):1787-95.

12. Preiser JC, Devos P, Ruiz-Santana S, Melot C, Annane D, Groeneveld J, et al. A prospective randomised multi-centre controlled trial on tight glucose control by intensive insulin therapy in adult intensive care units: the Glucontrol study. Intensive Care Med. 2009:35(10):1738-48.

13. Van den Berghe G, Wilmer A, Hermans G, Meersseman W, Wouters PJ, Milants I, et al. Intensive insulin therapy in the medical ICU. N Engl J Med. 2006;354(5):449-61.

14. Van Herpe T, Mesotten D, Wouters PJ, Herbots J, Voets E, Buyens J, et al. LOGIC-insulin algorithm-guided versus nurse-directed blood glucose control during critical illness: the LOGIC-1 single-center, randomized, controlled clinical trial. Diabetes Care. 2013;36(2):188-94.

15. Kulnik R, Plank J, Pachler C, Wilinska ME, Groselj-Strele A, Rothlein D, et al. Evaluation of implementation of a fully automated algorithm (enhanced model predictive control) in an interacting infusion pump system for establishment of tight glycemic control in medical intensive care unit patients. J Diabetes Sci Technol. 2008;2(6):963-70.

16. Boyd JC, Bruns DE. Effects of measurement frequency on analytical quality required for glucose measurements in intensive care units: assessments by simulation models. Clin Chem. 2014;60(4):644-50.

17. Wilinska ME, Hovorka R. Glucose control in the intensive care unit by use of continuous glucose monitoring: what level of measurement error is acceptable? Clin Chem. 2014;60(12):1500-9.

18. Blaha J, Kopecky P, Matias M, Hovorka R, Kunstyr J, Kotulak T, et al. Comparison of three protocols for tight glycemic control in cardiac surgery patients. Diabetes Care. 2009:32(5):757-61

19. Dumont C, Bourguignon C. Effect of a computerized insulin dose calculator on the process of glycemic control. Am J Crit Care. 2012;21(2):106-15.

20. Knaus WA, Draper EA, Wagner DP, Zimmerman JE. APACHE II: a severity of disease classification system. Crit Care Med. 1985;13(10):818-29.

21. Vincent JL, Moreno R, Takala J, Willatts S, De Mendonca A, Bruining $\mathrm{H}$, et al. The SOFA (Sepsis-related Organ Failure Assessment) score to describe organ dysfunction/failure. On behalf of the Working Group on Sepsis-Related Problems of the European Society of Intensive Care Medicine. Intensive Care Med. 1996;22(7):707-10.

22. Rodbard D. The challenges of measuring glycemic variability. J Diabetes Sci Technol. 2012;6(3):712-5. 
23. Service FJ, Molnar GD, Rosevear JW, Ackerman E, Gatewood LC, Taylor WF. Mean amplitude of glycemic excursions, a measure of diabetic instability. Diabetes. 1970;19(9):644-55.

24. McDonnell CM, Donath SM, Vidmar SI, Werther GA, Cameron FJ. A novel approach to continuous glucose analysis utilizing glycemic variation. Diabetes Technol Ther. 2005;7(2):253-63.

25. Molnar GD, Taylor WF, Ho MM. Day-to-day variation of continuously monitored glycaemia: a further measure of diabetic instability. Diabetologia. 1972;8(5):342-8.

26. Kovatchev BP, Cox DJ, Gonder-Frederick LA, Young-Hyman D, Schlundt D, Clarke W. Assessment of risk for severe hypoglycemia among adults with IDDM: validation of the low blood glucose index. Diabetes Care. 1998;21(11):1870-5.

27. Finfer S, Wernerman J, Preiser JC, Cass T, Desaive T, Hovorka R, et al. Clinical review: consensus recommendations on measurement of blood glucose and reporting glycemic control in critically ill adults. Crit Care. 2013;17(3):229.

28. Boutin JM, Gauthier L. Insulin infusion therapy in critically ill patients. Can J Diabetes. 2014;38(2):144-50.

29. Barletta JF, McAllen KJ, Eriksson EA, Deines G, Blau SA, Thayer SC, et al. The effect of a computer-assisted insulin protocol on glycemic control in a surgical intensive care unit. Diabetes Technol Ther. 2011;13(4):495-500.

30. Dortch MJ, Mowery NT, Ozdas A, Dossett L, Cao H, Collier B, et al. A computerized insulin infusion titration protocol improves glucose control with less hypoglycemia compared to a manual titration protocol in a trauma intensive care unit. JPEN J Parenter Enteral Nutr. 2008;32(1):18-27.

31. Finney SJ, Zekveld C, Elia A, Evans TW. Glucose control and mortality in critically ill patients. JAMA. 2003;290(15):2041-7.

32. Hovorka R, Kremen J, Blaha J, Matias M, Anderlova K, Bosanska L, et al. Blood glucose control by a model predictive control algorithm with variable sampling rate versus a routine glucose management protocol in cardiac surgery patients: a randomized controlled trial. J Clin Endocrinol Metab. 2007;92(8):2960-4.
33. Krinsley JS, Preiser JC. Time in blood glucose range 70 to $140 \mathrm{mg} / \mathrm{dl}>80 \%$ is strongly associated with increased survival in non-diabetic critically ill adults. Crit Care. 2015;19:179.

34. Marvin MR, Inzucchi SE, Besterman BJ. Computerization of the Yale insulin infusion protocol and potential insights into causes of hypoglycemia with intravenous insulin. Diabetes Technol Ther. 2013;15(3):246-52.

35. Plank J, Blaha J, Cordingley J, Wilinska ME, Chassin LJ, Morgan C, et al. Multicentric, randomized, controlled trial to evaluate blood glucose control by the model predictive control algorithm versus routine glucose management protocols in intensive care unit patients. Diabetes Care. 2006;29(2):271-6.

36. Saager L, Collins GL, Burnside B, Tymkew H, Zhang L, Jacobsohn E, et al. A randomized study in diabetic patients undergoing cardiac surgery comparing computer-guided glucose management with a standard sliding scale protocol. J Cardiothorac Vasc Anesth. 2008;22(3):377-82.

37. Shetty S, Inzucchi SE, Goldberg PA, Cooper D, Siegel MD, Honiden S. Adapting to the new consensus guidelines for managing hyperglycemia during critical illness: the updated Yale insulin infusion protocol. Endocr Pract. 2012;18(3):363-70.

38. Vogelzang M, Zijlstra F, Nijsten MW. Design and implementation of GRIP: a computerized glucose control system at a surgical intensive care unit. BMC Med Inform Decis Mak. 2005;5:38.

39. Steil GM, Deiss D, Shih J, Buckingham B, Weinzimer S, Agus MS. Intensive care unit insulin delivery algorithms: why so many? How to choose? J Diabetes Sci Technol. 2009;3(1):125-40.

40. Wilson M, Weinreb J, Hoo GW. Intensive insulin therapy in critical care: a review of 12 protocols. Diabetes Care. 2007;30(4):1005-11.

\section{Submit your manuscript to a SpringerOpen ${ }^{\circ}$ journal and benefit from:}

- Convenient online submission

- Rigorous peer review

- Immediate publication on acceptance

- Open access: articles freely available online

- High visibility within the field

- Retaining the copyright to your article

Submit your next manuscript at springeropen.com 